\title{
Chronic Ulcers and Myasis as Ports of Entry for Clostridium tetani
}

\author{
Jiuseppe Benitivoglio Greco, Edilson Sacramento \\ and José Tavares-Neto
}

Bahia School of Medicine and Public Health,
HospitalCouto Maia, School of Medicine-Federal
University of Bahia, Salvador, Bahia, Brazil

\begin{abstract}
Evaluating tetanus immune status is not yet the usual clinical practice regarding patients with chronic ulcers or myasis. However, of 858 tetanus patients at Hospital Couto Maia (Salvador, Bahia, Brazil) aged 1 year or above, 2 had pressure ulcers and 17 had chronic ulceration of the lower limbs where these skin lesions were the ports of entry for Clostridium tetani. In these 19 cases, the following predisposing factors were described: venous insufficiency $(n=6)$, sickle cell anemia $(n=2)$, Hansen's disease $(n=1)$, malnutrition $(n=1)$, diabetes mellitus $(n=1)$, trauma $(n=1)$ and unknown factors $(n=7)$. In 6 other cases, in addition to the Hansen's disease patient, the port of entry for tetanus was the site of extraction of Tunga penetrans larvae. In these 25 cases, the majority of patients $(68 \%)$ were over 40 years old $(17 / 25)$ and all of these patients stated that they had either not followed a tetanus toxoid vaccination regimen (19/25), or had partially completed such a regimen, or did not give precise information (6/25). Among the same series studied, over half $(52 \%)$ of the patients died (13/25). We conclude that tetanus prevention must be included in the treatment of chronic skin ulcer patients, vaccination coverage should be increased among older people, and strategies aimed at improving coverage for all age groups must be reviewed. Key Words: Tetanus, chronic leg ulcer, venous leg ulcer, sickle cell disease, Hansen's disease, Tunga penetrans, Clostridium tetani.
\end{abstract}

Chronic skin lesions of venous, arterial, infectious or parasitic origin are rarely described as ports of entry for Clostridium tetani in the medical literature [1-3]. Angiology and vascular surgery textbooks and other publications in those fields $[4,5,6-8]$ do not mention chronic leg ulcers [6] of venous or arterial origin, or associated with sickle-cell anemia or rheumatoid vasculitis [7], as potential ports of entry for tetanus.

It is not unusual to find that the ports of entry for tetanus patients treated at Hospital Couto Maia (HCMaia, Salvador - Bahia) are chronic leg ulcers, pressure ulcers, bedsores, supra-malleolar ulcers associated with sickle-cell anemia, leishmaniotic ulcers

Received on 14 September 2001; revised 12 December 2001.

Address for correspondence: Dr. Jiuseppe B. Greco - Travessa Baependi, 09, Ondina. Zip Code: 40170-090, Salvador, Bahia, Brazil.E-mail: greco@e-net.com.br

The Brazilian Journal of Infectious Diseases 2001;5(6):319-323. (C) 2001 by The Brazilian Journal of Infectious Diseases and Contexto Publishing. All rights reserved.

1413-8670
(Leishmania braziliensis), or Tunga penetrans. In view of these clinical observations, the objective of presenting this series of tetanus cases was to describe which of them involved chronic ulcers or myasis as ports of entry.

\section{Materials and Methods}

All records for tetanus patients treated at Hospital Couto Maia (HCMaia) treated between January 1, 1986, and December 1, 1997, were reviewed and the data was recorded using standardized forms, as long as the diagnoses followed previously established standards [9]. Run by the Bahia Health Department (SESAB) in the City of Salvador (State of Bahia, Brazil), this hospital treats nearly all patients with infectious and parasitic diseases in the Salvador Metropolitan Region and treated $71 \%$ to $79 \%$ of all cases of tetanus reported in the state between 1991 and 2001 (Epidemiology Division, SESAB, personal communication). 
Before undertaking a systematic review of this historic series, we listed the numbers of patient records from the HCMaia Epidemiological Surveillance Sector, the nosologic archives of the Archives and Statistics Department, and inpatient records. After we developed this data bank (using Excel ${ }^{\circledR}$ ), the patients' histories were reviewed by two independent observers. If an outside reviewer observed a discrepancy, all three authors analyzed the patient records and standardized forms. The forms included demographic, clinical-epidemiological (including port of entry for C. tetani), and therapeutic data, evolution during hospital stay, complications, length of hospital stay, and type of discharge. The data were analyzed using the SPSS program (v. 9.0).

\section{Results and Discussion}

During the 12-year period in question (1986 to 1997), 1,038 tetanus patients were admitted to HCMaia. Fourteen (1.4\%) were excluded because they did not meet inclusion standards. Among the cases studied ( $\mathrm{n}=1,024), 868(84.8 \%)$ had accident-related tetanus and $156(15.2 \%)$ had neonatal tetanus. Of all cases of accident-related tetanus studied, the patients' ages ranged from 1 to $96(32.7 \pm 21.8$ years of age $)$, the median being 24 years old. In the same group, $63.5 \%$ (551/868) were discharged from hospital, 307 $(35.4 \%)$ died, and $1.2 \%(\mathrm{n}=10)$ were transferred.

In the patients with accident-related tetanus who were discharged from hospital or died $(n=858)$, the port of entry for tetanus was not identified, and two or more probable ports of entry were described in $30(3.5 \%)$ patients. In cases where the port or ports were known, the majority $(56.9 \%)$ were located on or below the knee $(488 / 858)$, and of these cases, over two-thirds $(69.9 \%)$ were located on one foot or both feet $(341 / 488)$. Table 1 shows the characteristics of ports of entry according to the type of hospital discharge (sent home or deceased), but the cases in which the port of entry resulted from intramuscular injection were most frequently found among the patients who died $(p<0.004)$. These results agree with those observed in the literature and recently reviewed by Greco [9].
As shown in Table 1, 17 patients (2.0\%) had chronic ulcers due to several different causes or predisposing factors, which are described in Table 2 . In addition to case no. 16, 6 cases of myasis in previously healthy patients and 2 cases of pressure ulcers are also described in Table 2.

When analyzing records of tetanus cases at Hospital Couto Maia, Greco [9] found that 35.0\% (300/858) of the patients were 41 or older; $73.7 \%$ (14/19) of all chronic and pressure ulcer patients were in this age group, which is when venous and arterial pathologies are more frequent among other predisposing factors [4, 5-8]. Another aspect observed was the high mortality rate (52.0\%) among the cases described in Table 2 (13/25), $57.9 \%(11 / 19)$ of which involved chronic ulcers. An analysis of Hospital Couto Maia's records, excluding neonatal tetanus cases, found that the mortality rate was $35.4 \%$ [9]. This could be explained by the fact that the patients in this series were more frequently included in the over-40 group, as older tetanus patients are more strongly associated with a bad prognosis $[9,10]$. This is further proof of the need for tetanus prevention among older people.

One reason for tetanus prevention is that a lack of preventive tetanus vaccinations or ignorance of prior immune status was commonly found in the 25 cases described in Table 2. Many of these cases (16/25) involved long-term chronic skin lesions present from 8 months to over 10 years. These 16 patients probably sought medical care due to other prior or concomitant diseases, and evidently no attention was paid to their tetanus immune status.

In Brazil, in the north and northeast in particular, there is a very high frequency of lost immunization opportunities, even for vaccines provided by the Health Ministry's National Immunization Program, including children and adolescents [11]. This serious situation is worsened by the fact that there are signs that physicians and medical students have fairly little knowledge of vaccines and vaccination regimens $[12,13]$. There is also a high degree of ignorance about tetanus and vaccination histories among adult patients $(63.5 \%$ and $20 \%)$ and health workers $(30.3 \%$ and $21.2 \%$ ) at the university hospital in the city of Salvador, 
Table 1. Characteristics of ports of entry for accident-related tetanus in patients at Hospital Couto Maia (Salvador, Bahia) sent home or deceased between 1986 and 1997

\begin{tabular}{|c|c|c|c|}
\hline \multirow[b]{2}{*}{ Port of entry - characteristics } & \multicolumn{3}{|c|}{ Type of hospital discharge $n(\%)$} \\
\hline & Sent home & Deceased & Total \\
\hline Superficial & $160(29.0)$ & $67(21.8)$ & $227(26.4)^{*}$ \\
\hline Deep-without suture & $95(17.2)$ & $74(24.1)$ & $169(19.7)^{*}$ \\
\hline Deep - with suture & $119(21.6)$ & $73(23.8)$ & $192(22.4)^{*}$ \\
\hline Intramuscular injection & $1(0.2)$ & $7(2.3)$ & $8(0.9)^{\mathbf{a}}$ \\
\hline Puncture hole (thorns, sticks, etc.) & $85(15.4)$ & $40(13.0)$ & $125(14.6)^{*}$ \\
\hline Iatrogenic (surgery, prostheses, etc.) & $14(2.5)$ & $12(3.9)$ & $26(3.0)^{*}$ \\
\hline Ulcers & $7 \quad(1.3)$ & $10(3.3)$ & $17(2.0)^{*}$ \\
\hline Dental & $14 \quad(2.5)$ & $4 \quad(1.3)$ & $18(2.1)^{*}$ \\
\hline Unknown & $56(10.2)$ & $20 \quad(6.5)$ & $76(8.9)^{*}$ \\
\hline Total & $551(64.2)$ & 307 (35.8) & $858(100.0)$ \\
\hline
\end{tabular}

$\left(^{*}\right) \mathrm{p}>0,05$; (a) Fisher Exact Test $\mathrm{p}<0,004$.

Bahia [14]. Therefore, it seems consistent to observe a high frequency of patients with chronic diseases and cutaneous lesions who are at risk of incurring a secondary infection and are not protected against tetanus.

It has been observed that secondary infection due to aerobic bacteria is extremely frequent (90.4\%) in patients with American tegumentary leishmaniasis (Leishmania braziliensis) [15]. Two-thirds $(78.6 \%)$ of patients who had these cutaneous ulcers for 2 to 20 weeks mentioned prior treatment with herbal plasters, that are widely employed in folk medicine, and that have the potential to contain C. tetani spores. Despite the lack of data, we can infer that this might have been the mechanism involved in transmitting tetanus to the cutaneous ulcer patients listed in Table 2, particularly those who also had myasis. It is commonly observed in clinical practice that these patients describe a vast range of home remedies and therapies, which also represent a significant obstacle to health care in Brazil.
For many reasons, including the long duration of disease and the age of the patients, home remedies are probably common among people with varicose ulcers. It was also observed that the age of the patients (when over 50) was strongly associated with a higher risk of death $[9,10]$. However, tetanus vaccination for such patients is not mentioned in the angiology and vascular surgery textbooks $[4,6]$, even though articles published in the last 8 years recommend tetanus prevention for these patients $[1-3,16]$.

An annual immunization program for people over 65 was started in Brazil in 1999, and may help reduce the risk of tetanus for patients with varicose ulcers. However, the country lacks a tetanus immunization program for the general population over school age (except pregnant women). This may contribute to the general ignorance regarding vaccination history among people over 20 [14].

Similarly, there are no recommendations regarding tetanus vaccination for those with sickle cell anemia [6], especially those with malleolar ulcers, despite the 


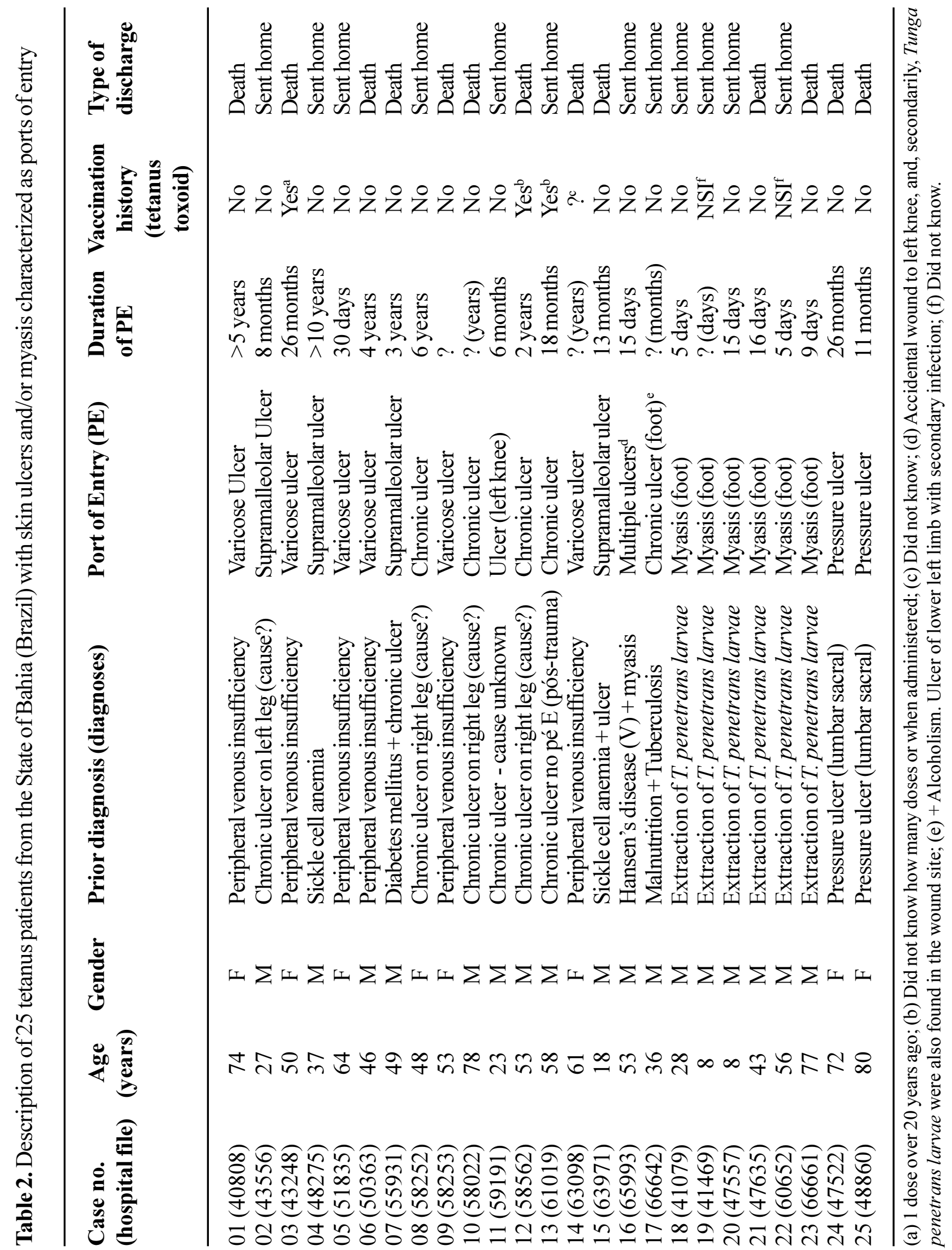


significant frequency of patients with this hemoglobinopathy in Brazil. The two cases described might seem to be statistically fortuitous, considering that $85 \%$ of the residents of the Salvador metropolitan region (State of Bahia) are of African descent [17], a sickle cell anemia and sickle cell trait. However, other possibilities should be considered, suchas: a) the shorter lifespan of sickle-cell anemia patients causes a smaller number of cases of malleolar ulcer as a port of entry for tetanus; $b$ ) the higher frequency of acute hemolytic crises could be associated with a higher level of medical care, increasing the possibility of tetanus prevention; c) under-notification of cause of death, as the greater seriousness of hemolytic crisis in the course of the infectious process could distort diagnostic indicators for tetanus in sickle cell patients. However, tetanus in sickle cell patients can still be considered a mere scientific curiosity, except for the article by Konotey-Ahulu [18].

Another situation with a potential risk of wounding, myasis and consequently tetanus, as in case 16, is observed in people with Hansen's disease, particularly those with polar forms of the disease that affect the sensitivity of the peripheral nerves and increase the risk of trauma. However, the specialized literature and technical standards do not include Hansen's disease patients among those for whom tetanus vaccination is recommended [19].

In conclusion, tetanus vaccination must be provided for people with chronic skin ulcers, sickle cell anemia and Hansen's disease. It is also necessary to review strategies aimed at increasing tetanus vaccination coverage in Brazil, particularly for older individuals. Furthermore, because myasis is a common problem in rural populations, where there is apparently less vaccination coverage than in urban areas, it is also necessary to improve sanitation conditions, and expand health education programs and health care.

\section{References}

1. Fernandes N.C., Pereira N.G., Martins M.M.C., Eiras M.V. Úlcera angiodérmica, mal perfurante plantar, escara de decúbito e tétano. An Bras Dermatol 1995;70:11-5.

2. Luisto $M$. Unusual and iatrogenic sources of tetanus. Ann Chir Gynaecol 1993; 82:25-9.

3. Prospero E., Appignanesi R., D’Errico M.M., Carle F. Epidemiology of tetanus in the marches region of Italy, 19921995. Bull. World Health Organization 1998;76:47-54.
4. Moneta G.L., Nehler M.R., Chitwood R.W., Porter J.M. The natural history, pathophysiology, and nonoperative treatment of chronic venous insufficiency. In: Rutherford RB (ed.), Vascular Surgery. Fourth edition, volume II, Philadelphia: WB Sauders, 1995.

5. Caillard P., Bahnini A., Negro D., Belliard J.P. Les ulcères de jambe d'étiologie veineuse: problèmes particuliers des ulcères mixtes. Phlébologie 1999;52:433-6.

6. Thomaz J.B. Úlcera de estase venosa. In: Thomaz JB (ed.), Angiologia e Cirurgia Vascular. Rio de Janeiro: REVINTER 2000: 129-42.

7. Thomaz J.B. Úlcera na anemia de células falciformes. In: Thomaz JB (ed.), Angiologia e Cirurgia Vascular. Rio de Janeiro: REVINTER 2000:143-8.

8. Thomaz J.B. Úlcera de perna na doença reumatóide. In: Thomaz JB (ed.), Angiologia e Cirurgia Vascular. Rio de Janeiro: REVINTER 2000:149-55.

9. Greco JB. Características clínico-epidemiológicas do tétano em pacientes de hospital de Salvador (Bahia). Tese de Doutorado, Escola Baiana de Medicina e Saúde Pública, 2001.

10. Miranda-Filho D.B., Ximenes R.A.A., Bernardino S.N., Escarião AG. Identification of risk factors for death from tetanus in Pernambuco, Brazil: a case-control study. Rev Inst Med Trop São Paulo 2000;42:333-9.

11. UNICEF. Bahia: suas crianças e adolescentes. Ministério da Ação Social/Centro Brasileiro para a Infância e Adolescência. UNICEF, Brasília, 1991 [mimeog.].

12. Moreira L.A.C. Avaliação do conhecimento dos pediatras de Salvador sobre a vacina anti-sarampo. Dissertação de Mestrado, Faculdade de Medicina da Universidade Federal da Bahia, 1994.

13. Gonçalves H.R., Tavares-Neto J., Lobato A.L.S., et al. Avaliação do conhecimento sobre a vacina DPT entre estudantes de Medicina do Brasil. Rev Soc Bras Med Trop 1995;28 (supl. I):318.

14. Aragão I., Ramos J.H., Coutinho E., et al. Conhecimento de indivíduos adultos sobre tétano, procedentes de hospital universitário (Salvador, Bahia). Rev Baiana Saúde Públ 1999;23: 99-104.

15. Vera L.A., Santos J.B., Macêdo V.O., Magalhães A.V., et al. Avaliação da influência da infecção bacteriana secundária na evolução da leishmaniose cutânea em Corte de Pedra, Bahia. Revista da Sociedade Brasileira de Medicina Tropical 2001;34:233-7.

16. Hafner J, Brunner U, Burg G. Treatment guidelines for venous leg ulcers: causal therapy initiation and local wound treatment. Ther Umsch 1996;53:304-8.

17. Azevêdo E.S. Subgroup studies of black admixture within a mixed population of Bahia, Brazil. Ann Hum Genet 1980;44:55-60.

18. Konotey-Ahulu FI. Death from tetanus in sickle-cell disease. LANCET 1992;340:1288.

19. Pena G.O. Doenças Infecciosas e Parasitárias. Aspectos clínicos, de vigilância e medidas de controle. $2^{\mathrm{a}}$ ed., Ministério da Saúde (CENEPI/FUNASA), Brasília 2000;95-8. 